\title{
Paradox: The Way of the Peaceful Warrior
}

\author{
Fengjuan $\mathrm{Wu}$ \\ School of foreign languages \\ Wuhan Textile University \\ Wuhan, China, 430073 \\ E-mail: birderry@sina.com
}

\author{
Zhengshun Han \\ School of foreign languages \\ Wuhan Textile University \\ Wuhan, China 430073 \\ E-mail: hanzhengshun@126.com
}

\begin{abstract}
The American movie Peaceful Warrior is adapted from the very first book entitled Way of the Peaceful Warrior by Dan Millman, a former world champion athlete, university coach, martial arts instructor and college professor. His twelve previous best-sellers have inspired millions of readers in twenty-nine languages. The script selected, paradoxically, only ten pages of the original. As such, it received mixed reviews. It relates a story about Dan, the protagonist, a university student favored by god, enjoys all the essential elements: a rich family, handsome looks, good grades, girls' Mr Right, a master of rings, and high intelligence coveted by many. So, he enjoys a wonderful life, manifests a temperament of wildness and self-pride. Out of expectation, his psyche is a barren field of desolation and emptiness, suffering from restlessness. He roams over the streets at midnight on one occasion, until he encountered an senior, weird but agile and wise old man of 96 years old - Socrotes - who renders service at 24-hour gas station. From then on, they become studentteacher relationship. Soc instructs Dan systemically, and teaches him by doing practical lessons. The central concept of his philosophy is this: one must live entirely in the present moment. At no time is "nothing going on". there is an appropriate time existing for fighting and another for abstaining from violence. Dan learned to appreciate every moment, increased his gymnastic prowess and control himself. He also learned that service is the most noble action possible. This paper attempts to analyze the paradoxical elements form the following three dimensions: 1. Paradox haunts our entire life, even the title is nothing but a paradox, no more, no less. 2. The process from book to movie translation constitutes a more or less paradox. 3. A sample collection of paradoxical sayings in the book $/ /$ movie.
\end{abstract} thinking

Keywords-peaceful warrior; paradox; philosophical

\section{INTRODUCTION}

Literature review reveals that, in this country, there exists only one comment on this movie. That is the paper by Mr. $\mathrm{Xu}$ Xiaofeng titled The Warrior Philosophy Expressive of the Peaceful Warrior's Image World, published on Movie Literature in 2014 (issue 10, pp86-87). It analyzes the narrative structure and delineated its Warrior philosophy. It holds that "The art of movie represents the warrior spirit in real life, encourages people to harbor hopes and aspirations towards life, and develops their warrior spirit to cope with the harsh and cruel life. " Outside this country, this movie received mixed reviews, even bordering on negative one.
Currently, holding a 25\%"rotten" rating from Rotten Tomatoes: the consensus of it states:"Based on a best selling memoir, Peaceful Warrior loses something in the transition from page to screen. It hits the viewer over the head with philosophical jargon, and ultimately fails to live up to its source material. "On Matacritic, this movie has a 40/100 rating, which indicates" mixed or average reviews. "However, many viewers praise this movie's acting, script. It presently holds a 7. 4/10 rating at IMDb. (Peaceful Warrior, Wikipedia. p4). Brian E. Erland comments thus:'Peaceful Warrior is one of those rare films that both entertains and teaches without sacrificing one for the other. The production values are high, the dialogue believable and the performances strong. ---the message is so well presented and the actors so amiable and any minor gliches are forgivable. "(Brian E. Erland. Customer Review. July 2. 2007). These fully manifest the mixed nature of the reviews."Its plot is cliche, but the lines are well worth chewing and digesting (Peace Warrior Movie Review). Nevertheless, the author of this paper contends that it is the thread of paradox that runs through the entire texture of this movie/books.

\section{PARADOX DOMINATES AND HAUNTS OUR LIFE, AS WITH THE TITLE OF THIS MOVIE}

Paradox makes this cosmic fact self-evident: we actually live in a world of duality such as light and darkness, good and evil, and the both simultaneously exist. Just as what Charles Dickens says at the beginning his famous book of A Tale of Two Cities:"It was the best of times, it was the worst of times, it was the age of wisdom, it was the age of foolishness, it was the epoch of belief, it was the epoch of incredulity, it was the season of Light, it was the season of Darkness, it was the spring of hope, it was the winter of despair, we had everything before us, we had nothing before us, we were all going direct to Heaven, we were all going direct the other way - in short, the period was so far like the present period, that some of its noisiest authorities insisted on its being received, for good or for evil, in the superlative degree of comparison only. (https://en.wikipedia. org/wiki/A_Tale_of_Two_Cities)

Even within the sphere of our psyches, we can find such polarized characters like: the puritan versus the hedonist; the believer versus the doubter; the social butterfly versus the lone wolf. Paradox pervades not only our life but also our psyche and even in the mystery of our existence. 
In our everyday life, we can encounter a variety of paradoxical truths, for instance, we are separate, but we are one. Accidents happen, but here are no accidents. Death is real, but death is an illusion. These two views are both valid from their respective conventional or transcendental point of perspective.

Even the idea of "living in the present moment" can be considered as a paradox since the present moment dosen't actually exist at all. This is because when we utter the word now, between nnnn and owww a thousand moments have come and gone. We can neither grasp the moment nor seize the day. All we can do is just go with the flow of time. To be frank, there's no past, no future, and no present---no time at all. By the term, "staying in the present", we mean focusing on what's right in front of us, not getting preoccupied with either memories or imagined future. (Although the past and future may be very nice places to visit, we don't want to live there at all.)

The same is true with the title of this movie itself Peaceful Warrior-nothing but a paradox, no more, no less. how can we be both at the same time? Notwithstanding, when these two apparent opposites are combined together, they form a whole which is far greater than the total sum of the respective parts-love and courage-a peaceful heart plus a warrior spirit.

Consequently, in a sense, the more we accept paradox, the more skillfully we ride the river of reality. So why don't we make peace with paradox. Please allow me to bring this part to an end by quoting the Japanese poet Masahide's famous say: "Now that my house has burned down, I have a better view of the rising moon." (Dan. Wisdom of the Peaceful Warrior. pp69-70)

\section{THE PROCESS FROM BOOK TO SCREEN TRANSLATION ALSO CONSTITUTES A MORE OR LESS PARADOX}

Now, first thing first, let us look at how the writer of the book view this movie: "I'm grateful that a film company was willing to invest millions of dollars to adapt my story to the film medium. "However, paradoxically:'I had no say over choice of director or actor---nor did I have any control over the script. "Several years ago, he had written his own script, but (in a very odd way), the producers and directors only looked through it for a few weeks, then the principal photography began. Nevertheless, the director incorporate about 10 pages of his script, adding some new scenes, and some dialogues into the final film. Except this small portion of contribution, for me, this project was actually an education in terms of "stepping back, letting go, and supporting the filmmakers in this collaborative art form." (Comments: The Peaceful Warrior Movie).

Objectively, this movie only loosely follows the overall conception of the book which is based intensely on incidents in the author's life. After watching a private screening, the author concludes that all in all, this movie had some quality moments, and managed to convey some of the spirit and teachings from the book. Like most book-to-film renderings, it tells a deeper story. Still, this movie has become something of a classic in the realm of spiritual cinema for it has inspired many movie fans who seek reminders about what really matters in real life. What's regretful is that many paradoxical truths that surface in books remain invisible in the movie thanks to the limitations of this medium. Only both readers of the books and the movie-goers can tell the difference. They can measure the weight and value of these sayings, isn't this paradoxical? The writer of the paper insists that even the author sometimes remain helpless concerning this translation. Let's drop this matter for now.

\section{A SAMPLE COLLECTION OF PARADOXICAL SAYINGS IN THE BOOK/MOVIE CHANGES AND TRANSFORMS OUR ENTIRE LIFE FROM WHICH WE BENEFIT FOR LIFE.}

In the books/movie (some may be missing), these paradoxical truths dot everywhere. For instance: 1. "The journey is what brings us happiness, not the destination." 2 . "If you don't get what you want, you suffer; if you get what you don't want, you suffer; even when you get exactly what you want, you still suffer because you can't hold on it forever." 3. "Happiness is like a butterfly: The more you chase it, the more it eludes you. But if you turn your attention to other things, it comes and sits softly on your shoulder"-Thoreau. 4. "When we travel in a great circle only to return to the point where we began, we may end up in the same place, but with a difference. We have made the journey and explored the periphery of the circle." 5. "All know the way, but few walk it"-Bodhidharma, the Buddhist patriarch. 6. "Many knock, but few enter." 7. "I've had many troubles in my life, most of which never happened." -Mark Twain. 8. In letting go of the smaller self, I awoke to a larger life. 9. We live as Socrates did-conventional lives, with unconventional perspectives. 10. "Dream big, but start small, Then connect the dots". 11. "An expert is someone who knows more and more about less and less until he knows everything about nothing." -Socrates on the the strengths and limitations represented by a degree. 12. "Art is a lie that helps us wee the truth" Pablo Picasso. 13. "The secret of happiness, you see, is not found in seeking more, but in developing the capacity to enjoy less." 14 . Whatever goes up must come down. 15. Change the past, change the future so on and so forth. These inspire us, set us thinking, leave us an indelible impression and also make it interesting and enjoyable with profound afterthoughts. But in the movie, can these be fully and totally presented? I doubt. What a paradox? How paradoxical!

\section{CONCLUSION}

From above, paradox dominates our life, as with the title of this movie/books. More paradoxical is the process from script to screen. Moreover, paradoxical truth scatter this movie/book here and there, entirely woven into the story. In general, most reviewers focus their attention on the internal dialogue towards the end of the film: "Where are you, Dan?" -"Here." "What time is it?" - "Now". "What are you?" "This moment." It is due to it that Dan gained athletic prowess and performed actions impossible and inaccessible to others, thereby winning the World Champion on rings. So to speak, "Living for the moment" illustrates the "way" because we do not remember days, instead we remember 
moments for life is a series of moments. No matter what our opinions or beliefs are, it remains a universal truth that the quality of each moment pretty much determines that of our lives. In other words, there is no ordinary moments. (Dan. Wisdom. p115)

But what holds the full attention of the author of this paper is the small faint-glowed card of Soc, in embossed letters, it states:

- Warrior, Inc.

- Socrates, Prop.

- Specializing in:

- Paradox, Humor, and Change.

The three eternal truths on which Soc builds his message and teachings, which also summarize the state of world, life and the universe--a trinity of sort.

Among them, change is directed at the cosmos which is perpetually moving and evolving; while humor refers to the attitude that we must hold towards life. We are living the soap opera each and every moment, aren't we? It hence can be drawn that paradox, in general, also what Soc places as the very first among three, constitutes the very and only way of the Peaceful World:keep a peaceful and loving heart, meanwhile, hold the courage, bravery and fortitude of a warrior. This remains the marvelous interpretation and total sum of the marrow and quintessence of a real peaceful warrior, don't you see eye to eye with me?

\section{REFERENCE}

[1] Amazon. com Review . Way of the Peaceful Warrior: A Book That Changes Lives. http://www. langlang. cc/2206017. htm.

[2] Dan. Comments: The Peaceful Warrior Movie. http://www. peacefulwarrior. com/index. Php Peaceful Heart, Warriot Spirit. Dan Millman presents The Peaceful Warrior's Way.

[3] Ehert Roger Peaceful Warrior review . http://www. qc99. com/wenxue/yingshi/yingwen/12273. Html. 03/01.

[4] Erland E. Brian. . Customer Review. http://www. amazon. com/review/R24UZOL4USSRJZ. July 2, 2007.

[5] Millman Dan (author), Liangyi Han(translator). Encountering Socrates in Midnight at Gas Station. Hangzhou:Zhejiang People's Press. 2013. 4.

[6] Millman Dan. Wisdom of the Peaceful Warrior. Navato:New World Library. 2006.

[7] Peaceful Warrior. From Wikipedia, the free encyclopedia. http://www://en. wekipedia. org/wiki/Peaceful Warrior.

[8] Peaceful Warrior Movie Review. http://blog. sina. com. $\mathrm{cn} / \mathrm{s} /$ blog_9398c0040100y1c3. html. (2011-10-26 22:01:35).

[9] Reflections After Watching the Peaceful Warrior Movie Review. http://www. fsdpp. cn/article/12963746792909. html. 01-30.

[10] The start of A Tale of Two Cities. https://en. wikipedia. org/wiki/A_Tale_of_Two_Cities.

[11] Xiaofeng Xu. "The Warrior Philosophy Expressive of the Peaceful Warrior's Image World”. Movie Literature. 2014(issue 10, pp86-87). 